U.Ü. FEN-EDEBIYAT FAKÜLTESI

SOSYAL BILIIMLER DERGISI

Yıl: 17, Sayı: 28, 2015/1

\title{
OYUNUN KURALLARINI YOK SAYMAK: HEATH W. LOWRY'YE CEVAP
}

Ayşegül KILIÇ*

\section{ÖZET}

Bu makale, 2011 yllında Gazi Evrenos Bey üzerine tamamladı̆̆ım doktora tezimin ardından yayınlanan diğer makalelerimde tekrar ettiğim bazl yeni bulgular üzerine tarihçi Heath $W$. Lowry ile başlayan polemik ve iddialarımı içermektedir. Yayınlarımda ilk defa bahsettiğim, Gazi Evrenos Bey'in etnik menşei üzerine yeni bulgu ve belgelerin yanı sıra ulaştığım sonuçların da söz konusu tarihçi tarafından intihal yoluyla çeşitli vesilelerle yayınlandığını tespit ettim. Bunun üzerine aramızda başlayan akademik tartışma, son olarak kendisinin yayın kurulunda olduğu dergide yazdiğ cevapla devam etti. Burada hem kendi iddialarım hem de söz konusu tarihçinin kimi iddialarına karşı bilim camiasını mesele hakkında aydınlatmak amacıyla detaylı bir cevap kaleme alınmıştır.

Anahtar Kelimeler: Gazi Evrenos, Heath. W. Lowry, Pranko Lazarat, Prangi İsa Bey, Ayşegül Kıllı̧.

\section{ABSTRACT}

\section{Ignoring the Rules of the Game: Reply to Heath W. Lowry}

This article contains some of my claims and the polemics between historian Heath W. Lowry and I, which started on by publication of some of my articles containing the new evidences regarding Gazi Evrenos Bey, that I mentioned about before in my PhD thesis, completed in 2011. I detected that Mr. Lowry has plagiarized and published some material based upon the findings, documents, and conclusions that I mentioned first in my publications. The academic discussion on that matter between me and Mr. Lowry has continued with the current article which he wrote as a response to my claims and published in the journal where he is a

Yrd. Doç. Dr. Pamukkale Üniversitesi, Fen-Edebiyat Fak. Tarih Bölümü.

aysegulcali@pau.edu.tr/aysegulcali@yahoo.com-https://pamukkale.academia.edu/ 
member of the editorial board. There I present a detailed response to elaborate my claims, to enlighten the scientific community about the matter, and to answer some claims made by Mr. Lowry.

Key Words: Gazi Evrenos, Heath. W. Lowry, Pranko Lazarat, Prangi Isa Beg, Ayşegül Kılıç.

Hakikat denen şey hep bir kurgu olarak kendini gösterir ve hikâye formuna bürünür. Herkes her şey için delil bulabilir; yeter ki delilini destekleyecek bir hikâye bulmayı da becerebilsin. Heath W. Lowry, yakın tarihlerde kaleme aldığ1 "kritik" görünümlü yazısında (Lowry 2014: 475492), şahsıma yönelik mesnetsiz iddialara ve kendisi hakkındaki iddialarıma dair zayıf ve gerçek dışı cevaplar vererek, kendi hakikatini kuvvetlendirecek bir hikâye arayışına girmiştir. Çünkü doktora tezimi (Çalı 2011) Bir Osmanlı akıncı Beyi: Gazi Evrenos Bey (Kılıç 2014) adıyla yayınladığım kitabımın Önsöz'ünde, Lowry hakkında ileri sürdüğüm intihalde bulunduğu iddialarıma samimiyetle cevap beklediğim bu yazıda, maalesef Lowry her şeyin benim Önsöz'ümdeki iddialarımla başladığına dair bir hikâye kurgulamayı tercih etmiştir. Önsöz'de yazdıklarım Lowry'nin doktora tezim ve makalelerimde ulaştığım belge ve bulguları hiç rahatsız olmadan sahiplenerek kullandığı son kitabındaki iddialarına karşı, kendi kitabımın baskısından hemen önce eklenmiş iki paragraftan ibaretti. Benim entelektüel emeğimin ürünü bulguları sahiplenmesi yetmezmiş gibi kendi ayıbını örtbas etmek için akademik yayınlarıma ve akademik kimliğime de ağır bir saldırıda bulunması karşısında sinmek yerine Önsöz'ümde kısaca kendi iddialarımı sıralamıştım. Çünkü asıl hikâyeyi, oyunu kurallarına göre kimin oynadığını ve kimin oyunun kurallarını yok saydığını en iyi kendisi ve ben biliyoruz. $\mathrm{Bu}$ nedenle, oyunun kurallarını yok sayan kurt bir akademisyen tarafından oyuna getirilen genç bir akademisyen olarak etikten yoksun bu nahoş hikâyeyi bütün detaylarıyla akademik camiayla paylaşmaya karar verdim. Ama bu dünyada adalet yok diye adaleti aramaktan ve talep etmekten vazgeçecek de değilim. İşte başrollerinde H. W. Lowry'nin ve benim olduğum bir intihal ve pişkinlik hikâyesi.

Heath W. Lowry, yukarıda bahsettiğim son yazısında kişilik katli ve çarpıtmalarla açığa çıkan oyununun kurallarını ve benim akademik geleceğimle oynayabileceğini bana hatırlatma gereği duydu. Kendi ifadesiyle "oyunun kurallarını" hiçe sayarak ve yine kendi deyişiyle "suyu bulandırmak" marifetiyle meselenin özünü okuyucuların dikkatinden uzak tutmaya gayret ettiği anlaşılmaktadır. Asıl meseleyi dikkatlerden kaçırarak, yani benim doktora tezim ve makalelerimden yaptığı intihal iddialarıma hiçbir ikna ve tatmin edici cevap vermeden, akademik hayatının ustalık döneminin hakkını verdiğini görüyorum. Yılların tecrübesi ve usta kalemine diyecek bir şeyim yok. Türkiye'deki akademik çevresi ve ilişkileri sayesinde 
bu bulanıklığ 1 artırma gayretine ise benim gibi Türkiye'de yetişmiş, bir taşra üniversitesinde çalışan ve mesleğinin başında bir akademisyenin pek müdahale etme şansı da yok. Sadece, akademinin artık unutulmaya yüz tutmuş etik değerlerini en azından kendi hukukum açısından sessizce ve uzlaşarak geçiştirmeyi tercih etmeye niyetim olmadığını belirtmeliyim. Belki de tek imkânım olup biten her şeyi bütün açıklığ 1 ve detayları ile tarihe not düşmek olan bu yazıdan ibaret diyebilirim.

Bilindiği üzere, son zamanlarda özellikle tarihçiler arasında yaşanan, hukukî olmaktan çok ahlakî bir fenomen halinde karşımıza çıkan intihal sorunu o kadar ileri gitti ki bu konuya ayrılmış özel kitaplar yayınlanmaya başladı. Söz konusu kitaplara konu olan "bilim adamları" ise alnı açık, gözü pek ve şebekeleriyle beraber meydan okumaya devam etmektedirler. Meselenin hukuki boyutunun etkisiz olması bir yana insanların ahlaki olarak nasıl meydan okuyacak cesareti bulabildiklerine bugüne kadar hiç anlam verememiştim. Fakat bu insanları ve işleyen süreci yakından tanımanın tek yolu sanırım bununla mücadele etmek zorunda kalmaktır. Prof. Dr. Ali Birinci'nin Tarihin Kara Kitabı adlı eserindeki bir cümle, esasında sürecin nasıl işlediğini, yani akademisyenlerin intihali nasıl gizleyebildiğini veya ahlaksızlığ 1 akademik çevrelerinde nasıl meşrulaştırabildiklerini çok açık bir şekilde özetliyor: “...Çünkü en geniş mânâsıyla ahlâksızlık da teşkilâtlanmış bir takım oyunu veya "organize" bir suçtur. Bu hususta ilim ya bir ahlâkî önderlik vazifesi yapar veya ahlâksızlı̆̆a tâbi olur ve "baktın zamane uymadı sen uy zamaneye" diyen eyyamcı tavrın takipçisi olarak ahlâksızlar kervanına katılır ve diğer taraftan da ahlâk temsilciliği vazifesinde de, etrafi iğfâl ederek, berdevam olur.” (Birinci 2014) Ali Birinci'den aldığım yukarıdaki cümlelerin ironik bir yanı daha var. Burada konu edilen meseleyi ilk yayınladığım makalem, onun T.T.K. başkanlığı sırasında Belleten dergisinde yayınlanmıştı. Amerikalı tarihçi Heath W. Lowry ile aramızda yaşanan polemik sanırım Türk tarihçiliğinin Kara Kitabı'nda kendine önemli bir yer edinmeye adaydır. Bu nedenlerle, daha önce meseleyi fazla uzatmamak, dünyada ve Türkiye'de popüler, akademiksosyal ağ1 ve erişimi son derece geniş olan bir profesörle mücadeleye girişme isteksizliğim sebebiyle kitabımın Önsöz'ünde sadece iki paragraf ayırdığım iddialarımı artık daha ayrıntılı ve açıç̧a yazmanın vakti gelmiştir. Ünlü gazeteci Robert Fisk'in tespit ettiği gibi y1llarca Türk hükümetlerine yıllarca danışmanlık hizmeti vermiş resmi tarihçimizin "Türk akademik camiası ile dostça ilişkilerini” (Fisk 2011: 311) bilerek ve akademik geleceğimi düşünerek ayrıntılı cevap yazmaktan imtina etmiştim. Yazılarında tevazu göstererek, akademik geleceğimle oynamak istemediğini belirtmesine rağmen (ki kuzu postuna bürünmüş kurt intibaı bırakan bu ifade aslında istersem bunu yapabilirim anlamına gelir), pek çok kişinin şahitliğinde "sen bana saldırdın ben de sana saldıracağım" demesini, tez 
danışmanı hocama beni şikâyet etmesini, mümkün olan her akademik çevre içinde şahsımı küçük düşüren alaycı konuşmalarını şimdiye kadar sineye çekmek zorunda kaldım.

Detaylara daha fazla girerek okuyucuları sıkmamak için asıl hikâyeye dönmek istiyorum. Evvela, meseleyi başından itibaren takip etmeyen veya ilk defa haberdar olanlar için herkesin anlayacağı bir sadelikle anlatmakla başlamak istiyorum. Aksi takdirde Lowry'nin karmaşık hale getirmeye çalıştı̆̆ serencamı ifade etmek oldukça güç görünüyor.

Her şey Mart 2011 tarihinde savunduğum Gazi Evrenos Bey (Çalı 2011) adlı doktora tezimin başarı ile tamamlanmasından sonra başladı. Buradan sonra okuyucuların verdiğim tarihlere çok dikkat etmesini arz ediyorum. Doktora tezim ile 2014 yılında yayınladı̆̆ım kitabımın içeriği, küçük düzeltmeler ve bazı ekler dışında aynıdır. Bilmeyenler için tezimin özünden bahsetmek gerekirse, kısaca Evrenos Bey'in kökenine yıllar sonra getirilmiş yeni bir değerlendirme ile Evrenos Bey'in tüm siyasi ve askeri faaliyetleri ve vakıflarını da içermektedir. $\mathrm{Bu}$ çalışmada, mevcut ulaşabildiğim tüm arşiv belgelerinin yanı sıra, Bizans ve Osmanlı kaynakları ve dönemin muasır kaynakları inceleyip, Evrenos Bey'in şimdiye kadar olmayan biyografisini yazdım. Bu bağlamda, Gazi Evrenos'un kökeni hakkında benden önce yapılmış mevcut tüm çalışmaları eleştirel bir yaklaşımla yeniden değerlendirdim. Her doktora öğrencisinin hayali olan özgün bir metin ortaya çıkarmaya gayret ederken, vakıflarına ve vakfiyelere dair tüm bilgileri topladığım için Başbakanlık Osmanlı Arşivinden almış olduğum Arapça bir vakfiye dikkatimi çekti. Bu belge Gazi Evrenos'un torunu İsa Bey'e aitti. Belgede Gazi Evrenos Bey'in babasının şimdiye kadar hiçbir kaynakta geçmeyen, H. W. Lowry'nin de 2012 yılına kadar lakabı sandığı, belki de gerçek adı hakkında, dolayısıyla yüz yıldan fazla bir süredir tartışmalara konu olmuş etnik kökeniyle ilgili ipucu veren bir bilgiyle karşılaştım. Bu belgeden sonra tezimin özellikle Gazi Evrenos'un hayatını incelediğim birinci bölümünün kurgusunu tamamen değiştirdim. Artık her doktora öğrencisinin nihai hedefi olan bilimsel tartışmaya özgün bir katk1 yapacak materyale sahip olmuştum. Bu belge ile beraber, Gazi Evrenos'un etnik kökeni hakkında 19.yy'da Joseph Von Hammer ile başlayan ve E. Gibbons ile devam eden, 20.yy'da F. Köprülü gibi büyük tarihçilerin yazdıklarını yeniden okudum. Dikkat çekici bir şekilde daha sonraki yıllarda, Ö.L. Barkan, İ.H. Uzunçarşı1l, I. Melikoff, G. Goodwin, S. Shaw, C. Imber, P. Wittek, K. Karpat gibi daha yeni kuşakların hepsi az veya çok Evrenos Gazi'nin etnik kökeniyle ilgilenmeden geçmemişlerdi. Son yıllarda ise F. Başar'ın islam ansiklopedisi maddesinde etnik kökene dair görüşler derlenmiş, L. Kayapınar ve H. W. Lowry gibi daha yeni tarihçilerin de bu konuya hasrettikleri makaleler ve kitaplarında önemli yer ayırdıklarını fark etmiş̧tim. Bütün bu yayınlar, bulduğum belgenin iyi bir analizle doğru 
sonuçlara ulaştıracağını gösteriyordu. İlk işim bu konuda bütün yazılanları ve ileri sürülen görüşlerin kaynaklarını eleştirel bir yaklaşımla tahlil etmek oldu. H. W. Lowry de bu tartışmaların son halkalarından biri olarak yazdığ 1 The Nature of the Early Ottoman State (Lowry 2003; Lowry 2010), adl1 eserini bu konuya önemli bir ayırmıştı. Doğal olarak bu eserinde Gazi Evrenos'un etnik kökeni ve tarih sahnesine çıkış hikâyesine dair ileri sürdüğü tezlerini eleştirel bir yaklaşımla değerlendirmek zorunluydu. Bunu yaparken, kitabının Türkçe çevirisini kullandım ve İngilizce aslı ile karşılaştırdım. Bazı çeviri hataları olsa dahi temel tezlerini etkileyecek herhangi bir yanlışlık görmedim ${ }^{1}$. Ayrıca, H. W. Lowry'nin diğer yayınlarındaki yorumlarını da elbette inceledim. Nihayetinde elimdeki belgeden yola çıkarak kendi tezlerim ve tahminlerimi yazdığım doktora tezimi savunarak Mart 2011'de YÖK tez merkezine iletilmek üzere Ankara Üniversitesi Sosyal Bilimler Enstitüsüne teslim ettim. Bilindiği üzere bu tarihlerde YÖK tez merkezine gidildiğinde araştırmacılara okumaları için izin verilmekteydi. Ayrica bu tezin bir kopyası 27 Nisan 2011'den itibaren Dil ve Tarih Coğrafya Fakültesi kütüphanesinde kopya verilmemek kaydıyla araştırmacılara ve meraklılarına açık olarak kayda girmiştir. Bu yazıya konu olan meseleyi en başından ve kronolojik olarak takip etmek isteyen okuyuculara öncelikle doktora tezim veya kitabımdan Evrenos Bey Hakkında Araştırmalar, Tartışmalar ve Bazı Yeni Bulgular adlı bölüme başvurmalarını tavsiye ediyorum. Söz konusu bölüm okunduğunda H. W. Lowry'nin yaptıkları ve yazdıklarının temel sebebini anlamak kolaylaşacaktır.

Mart 2011'de kamuya mal olmuş doktora tezimden bir süre sonra Aralık 2011'de Türk Tarih Kurumu tarafından yayınlanan Belleten dergisinde “Evrenos Bey'in Kökeni Hakkında Tartışmalar ve Yeni Bir Değerlendirme" (Kılıç 2011a: 745-768) adlı makalem yayınlandı. Okuyucuların dikkatini yine makale tarihine çekmek istiyorum. Aralık 2011 tarihi itibariyle H. W. Lowry'nin mevcut yayınlarını inceleyerek Gazi Evrenos'un kökenleri hakkındaki tezlerini ve benim bu tezlere yönelik eleştirilerimi okumalarını salık veriyorum. Bir hatırlatma yaparak, H. W. Lowry'nin Haziran 2012'ye kadar tezimdeki yeni bulgularla ilgili tek bir satır yazmamış ve kullandığım vakıf belgesinden haberdar olduğunu gösteren tek bir yayınının çıkmamış olduğuna dikkat çekmek istiyorum. Türkiye'de amatör veya profesyonel olarak tarih bilimiyle ilgilenenler Türk Tarih Kurumu'nun Belleten dergisinin ciddiyetinden ve kalitesinden

1 Kendisi sözlü ve yazılı olarak bu çevirinin hatalı olduğunu benim yayınlarımdan sonra iddia etse de kitabın Türkçe çevirisi bugün itibariyle satılmaya devam etmektedir. Bunu düzeltmek için kendisinin herhangi bir girişimde bulunmadığını hatırlatmak isterim. 
haberdardır. Ciddi bir hakem heyeti incelemesinden geçmeden burada bir makalenin yayınlanması mümkün değildir. Benim makalem de iki uzman hakeme gönderilmiş ve hakemlerin yolladığı raporlar isimleri gizlenerek şeffaf bir şekilde Türk Tarih Kurumu'nca tarafıma resmi yazıyla bildirilmiştir. Hakemlerin her ikisi de bazı küçük düzeltme talepleri dışında makalemi yayınlanmaya değer bulmuştur. Hatta bu hakemlerden birinin şu satıllarını buraya aynen aktarmak yerinde olacaktır: "Bu makale sadece Evrenos Bey'in babası İsa Bey'in Slav menşeli olduğunu ve adının Pranko Lazarat olduğu şeklindeki tesbitler dolayısıla bile yayınlanmaya değerdir. Kaldı ki yazar konuya birçok değerli katkılarda bulunmaktadır. Ancak şu hususlara da dikkat çekmek istiyorum...” diyerek gördügü bazı eksiklikleri düzeltmemi talep etmiştir. Bilindiği üzere bu düzeltmeler yazar tarafindan yapıldıktan sonra yeniden aynı hakemlerin incelemesinden ve Türk Tarih Kurumu yayın kurulunun denetlemesinden geçmektedir. Okuyuculara bir kez daha bu makalenin yayınlandığ Aralık 2011 tarihinde H. W. Lowry'nin Evrenos Bey'in halen Katalan kökenli olabileceği ihtimali üzerinde durduğunu hatırlatmak isterim. Göreceklerdir ki H. W. Lowry'nin tezleri ile Gazi Evrenos Bey'in kökeni hakkında bu makaledeki görüşlerim arasında tek benzerlik dahi yoktur.

$\mathrm{Bu}$ arada şu anekdotu anlatmadan geçmek istemiyorum. Keza Heath W. Lowry'nin de bu anekdotlara ve şahitliklere önem verdiğini yazılarından anlıyorum. Kendisiyle ilk tanışmamız 8-9 Nisan 2011 tarihinde Bursa'da düzenlenen Orhan Gazi ve Dönemi Sempozyumu'na konuşmacı olarak katıldığı toplantıda oldu. Ben de bu sempozyuma dinleyici olarak katılmışıım. Akşam yemeği sırasında yıllardır yayınlarından faydalandığım tarihçiyle tanışma heyecanıyla yeni bitirdiğim tezimden ve yazmakta olduğum makalemden bahsettim. Ayrıca önemli bulgulara ulaştığımı ve onu çok ilgilendirdiğini, yakında da Belleten dergisinde yayınlayacağımdan bahsettim. Dahası, kendisinin tezlerini eleştirdiğimi ve yanlış anlamamasını da ekledim. Kendisi bana aynen şu sözleri söyledi: Ben hastayım ve artık çok fazla vaktim yok ve yazacağım çok şey var. Bu nedenle çok hizl yazlyorum ve günde 12 saat çalışlyorum. Hizlı yazarken elbette hatalarım olur ve sizin gibi gençlerin de bunlarl düzeltmesi gerekir. $\mathrm{Bu}$ sözleriyle ünlü bir tarihçinin tezlerini "akademik anlamda" eleştirmemden kaynaklı tedirginliğim de sona ermişti. Doktorasını yeni bitirmiş genç bir akademisyen olarak onun şöhretine yakışan olgun tavrıyla rahatlamıştım.

Kendisiyle ikinci görüşmemiz ise yine Bursa'da 4-5 Nisan 2012 tarihinde Sultan I. Murad Hüdâvendigâr Sempozyumu'na her ikimizin de konuşmacı olarak katılması vesilesiyle oldu. Bu sempozyum sırasında beş ay önce yayınlanmış (Aralık 2011) Belleten dergisindeki makalemden haberdar olmuştu. H. W. Lowry şahsıma özel olarak ilk defa benim makalede bahsettiğim vakıf belgesinin numarasını eksik verdiğimi ve aslında 
bu belgenin kendisinde de olduğunu ama yeni fark ettiğini ifade etti. Sempozyumun Tirilye/Bursa'da düzenlenen kapanış yemeğinde ise nihai patlamayı yaptı. Yemeğe katılanların arasından beni arka masaya yalnız konuşmaya davet etti. Azarlama tonuyla yaptığı uzun konuşmasında ona makalemde saldırdığımı ve haksızlık yaptığımı ve artık kendisinin de bana saldıracağını, zaten Erken Osmanlı Devletinin Yapısı adlı kitabın Türkçe çevirisinden çalıştığım için yanlış anladığımı, yüksek sesle ve herkesin içinde küçük düşürmeye çalışan bir tavırla söyledi. $O$ akşam eşim ve diğer akademisyenlerin yanında zor duruma düşmeme rağmen kendisinin bulunduğu konum ve yaşına hürmeten saygısızlık etmemeye çalışarak durumu geçiştirdim. Ancak Güzelyalı Feribot iskelesinden kendisini uğurlarken sert çıkışından dolayı da yemeği düzenleyen Prof. Dr. Yusuf Oğuzoğlu yanımızda iken özür dilediğini de belirtmeliyim. Bu olaylara şahit olan, önemli bir kısmı H. W. Lowry'nin yakın dostu tarihçilerin dışında şahsen tanıştığım ve yemekte bulunarak bu yaşanılanları doğrulayacak pek çok kişinin ismini sayabilirim. Sempozyum katılımcıları ve organizatörlerinin isimleri bellidir. Bazıları ise H. W. Lowry'nin kendi üniversitesinden meslektaşları ve bir kısım kadim dostları bu olayı hatırlayacaklardır. Herhalde Ali Birinci'nin deyimiyle bir "takım oyunu" içinde olmak istemeyeceklerdir. Bu hatıranın neden önemli olduğunu bir kez daha hatırlatayım. Çünkü benim Belleten'deki makalemin yayınlanmasından dört ay sonra nasıl haberdar olduğunu kendi kitabında anlatırken kendini ele vererek o güne kadar doktora tezimden ve makalemden habersiz olduğunu iddia etmektedir:

"2012 tarihli kitabımı yazdığım sırada, Bursa Osmangazi Belediyesi tarafindan 4-5 Nisan 2012 tarihlerinde düzenlenen 'Sultan I. Murad Hüdâvendigâr ve Dönemi' konferansına katıldım. Katılımcılar arasında Ayşegül Kılıç da bulunmaktaydı. Bu toplantı esnasında, yakın bir zamanda, A. ̈. Tarih Araştırmalart Dergisi'nde yayımlanan 'Bizans ve Osmanlı Kaynaklarında Gâzi Evrenos Bey'in Imajı Hakkında Bir Inceleme' başlıklı makalesinin bir ayrıbasım kopyasını nazikçe takdim etti. Hafizam beni yanıltmıyorsa, T. T. K. Belleten dergisinde kısa bir süre önce Evrenos'un etnik kökenine dair başka bir makale yayımladığından bahsetti, lâkin ya eline ulaşmamıştı, ya da elinde bana verebileceği bir ayribasım yoktu.

Aynı konu üzerinde yazdığım kitabımı yeni tamamladığım ve bu esnada Belleten'in mevzubahis sayısı elimde olmadığı için, İstanbul'a döndükten sonra İSAM kütüphanesinin Müdürü Mustafa Birol Ülker'i aradım ve bana Ayşegül Kılıç'ın Belleten'de yayımlanan makalesinin bir kopyasını göndermesini rica ettim. Birkaç gün sonra, 17 Nisan 2012 tarihinde [Not: Bu esnada kitabın metnini tamamlamış ve yardımcım Faruk Özbey ile birlikte kitabın mizanpajı üzerinde çalışmaya başlamıştık]. Ülker'den bir e-mail 
aldım. Bu maille Ayşegül Kılıç'ın “Evrenos Bey’in Kökeni Hakkında Tartışmalar ve Yeni Bir Değerlendirme" makalesini de eklemişti. Okuduktan sonra birkaç kilit noktada görüşlerimizin ve yorumlarımızın farklı olduğunu gördüm ve yeni tamamlamış olduğum çalışmama yazarın makalelerinin eleştirisini içeren bir "Ek" koymaya karar verdim. Bu bölüm, yalnızca bu iki makalenin içeriğine dayanmaktaydı, çünkü o esnada (eleştirimde açıkça belirttiğim üzere) ve bugüne değin, yayımlanmamış doktora tezinin bir kopyasını görmedim." (Lowry 2014: 481-482)

Kitap yazdığınız bir konuda, sizin kullandığınız materyallerin aynısını kullanan, aynı tezleri ileri süren bir makale Türkiye'deki en önemli tarih dergisinde yayınlanıyor, siz ise bundan dört ay sonra haberdar olduğunuzu ve aynı konuda bir yıl önce bitmiş bir doktora tezini merak bile etmeden görmediğinizi söylüyorsunuz. Ayrıca o zamana kadar Gazi Evrenos'un kökenine dair teorilerinizi bir kenara bırakıp bir buçuk yıl önce kullandığım belgeye ve sonuçlara ulaşarak görüşlerinizi birden değiştiriyorsunuz. Sanırım benim “iskambilden evim” H. W. Lowry'nin kurgusundan daha sağlam görünüyor. Evet, anlattığı gibi kendisine bir ayrıbasım getirmedim. Çünkü Belleten dergisi henüz bana da göndermemişti ve dergiye elektronik olarak ulaşılabilir durumda olduğundan beş ay önce çıkmış makalemi zaten görmüş olduğunu düşünmüştüm. Bu nedenle son çıkan başka bir makalemi hediye ettim. Yukarıda anlattı̆̆ına göre makalemi İSAM Kütüphanesi Müdürü Mustafa Birol Ülker'in kendisine göndermesinden sonra okuduğunu belirtmiş. Oysa makalemi daha önce gördüğünü ve haberdar olduğunu sempozyum sirasında tüm izleyicilerin karşısında ifade ettiğini hatırlatmak isterim. Konuşması sırasında Belleten'deki makaleme atıfta bulunarak, benim kullandığım belgenin numarasının yanlış olduğunu, zaten elindeki bir başka belgenin benim belgeye benzediğini ama referansların tutmadığını, henüz makaleyi detaylı okumadığını anlatarak Evrenos'un etnik kökenine dair bir kitap yazacağını ifade etti. Tabiî ki onun sözlü ifadelerini duyduğumu söylemek onun yukarıda anlattıklarını yalanlamaya delil olmaz. Ancak katılımcıların hepsi hatırlamasa dahi bu sempozyumun ses kayıtlarını ev sahibi Osmangazi Belediyesi'nden edindiğim için mevcut olduğunu biliyorum. Edindiğim ses kayıtlarının çözümlerini aktardığımda önceki beyanlarının baştan aşağı yalan olduğu açıkça ortaya çıkıyor. Sempozyumun bildiri kitabı önceden basıldığ için H. W. Lowry sunduğu bildiriyi veya konuşmalarını değil mevcut yayınlarından bir bölümünü bu kitapta yayınlamak üzere göndermiş. ${ }^{2}$

Sempozyum bildirilerinin basıldığı kitabın dipnotunda aynen şu şekilde yazmaktadır: " $B u$ makale Heath W. Lowry ve Ísmail Erünsal'ın Yenice-i Vardar'lı Evrenos Hanedanı: Notlar ve Belgeler (Bahçeşehir Üniversitesi Yayınları, İst. 2010) adı eserinde yayınlanmış 
(Lowry 2012b: 36) Yani sempozyumda sunduğu bildiri ile sempozyum kitabında yayınladığı metin aynı değil. Yukarıdaki anekdotunu yeniden hatırlatarak Belleten'deki makalemden 4-5 Nisan 2012'de tesadüfen haberdar olduğunu ve 17 Nisan'da, tam da kitabın İngilizce yazdığı kısmı yeni bitmişken eline geçmiş olduğunu söylerken aleni bir şekilde yalan söylemektedir. Burada yaptığı minareyi çalmadan önce kılıfı hazırlamaya yönelik son hazırlıklar olmalı. Ayrıca, söz konusu sempozyumdaki konuşmasında, görmediğini iddia ettiği makalemden bahsederek, burada benim belge numarasını eksik yazdığımı ve kendisinin bu konuda yeni bir belge bulduğunu sözlü olarak ifade etmiştir. $\mathrm{Bu}$ sempozyumun basıl1 kitabında bu ifadeleri olmadığı için ses kayıtlarına ulaştığımı belirtmiştim. Bursa Osmangazi Belediyesi'nde arşivlenen bu kayıtlarda (bir kopyasını verdikleri için teşekkür ederim ve talep eden herkese gönderebilirim) aynen şu cümleleri söylemiştir:

“ ... son çıkmak üzere, on dördüncü yüzyıl Osmanlı Gerçekleri, Hacı Gazi Evrenos'un İzinde, yarın öbür gün matbaaya gidecek. Biraz onun içindekileri sizinle ilk defa paylaşmak istiyorum. Aramızda genç bir arkadaşımız var Ayşegül (Kılıç). Ayşegül Hanım zannediyorum aynı belgeyi kulland, bir iki ay evvel yayınladığı bir makalede aynı belgeyi kullandığını biliyorum ama emin değilim, daha firsat bulamadım okumaya, çalıştığım için, çünkü onun verdiği referansla benim verdiğim referanslar tutmuyorlar birbirlerini, bu da Evrenos'un bir oğlu, Gazi İsa Bey, 1456 ve 1457 'de yapılan Yenice-i Vardar'da bir vakfiyesi. Ve bu vakfiyesinin bir özelliği, kendi ismiyle beraber işte İsa Beğ, ibn elemir el kebir, el merhum, eş-şehir, Evraniz veya Evranuz Bey gibi ... Pranko veyahut Branko Lazart. Biz Evrenos'un ... nereden geldiğini ve ne kökenli olduğunu bir bilgimiz yoksa bu bize yeni bir ipucu veriliyor. ...

Görüldüğü üzere H. W. Lowry'nin bahsettiği sempozyumdaki konuşması kendi yazdığı hikâye ile çelişmektedir. Makaleyi henüz okumadığını ama muhtemelen aynı belgeyi kullandığını fakat referanslar tutmadığı için emin olamadığını söylüyor. Öyleyse şu soruyu cevaplaması beklenir: $\mathrm{Bu}$ makaleyi okumadan veya doktora tezimi görmeden benim referansımın hatalı olduğunu nasıl anladınız acaba? Bundan daha önemlisi yukarıda kendi anlattığı hikâyenin sempozyumdaki ses kayıtlarıyla birbirini yalanlayan içeriğidir. Bu durumda ikisinden birinde yalan söylediği açıkça ortaya çıkmaktadır. H. W. Lowry, sempozyum kitabında sunduğu bildiriden farklı bir metnin yayınlanmış olduğunu bilmenin verdiği rahatlıkla kurgusunu bir yalan üzerine kurmuş görünüyor. Sahiden, hangi okuyucu

olup bu kitaba konulması için izin veren ve düzenlenen sempozyumda bu konuda bilgi vermeyi kabul eden Heath W. Lowry'ye teşekkür ederiz." 
veya sempozyum katılımcısı bunları hatırlayacaktır ki? Ancak bana karşı kullandığ1 "yalancının mumu" atasözünün anlamı tam da buraya uyuyor. Yazısında Ayşegül'ün makalesini 4-5 Nisan'daki sempozyumda öğrendim, 17 Nisan'da sonra İSAM'dan dostum bana gönderdi ve okudum. Tezinden de haberim yoktu. Ancak bu sıralarda zaten aynı konuyla ilgili kitap yazıyordum ve ne tesadüf ki aynı konuları çalışıyormuşuz ve aynı belgeye ulaşmışı şeklinde anlatıyor (Lowry 2014: 482). Oysa 4-5 Nisan'daki ses kaydında çoktan haberdar olduğu, makalemi okuduğu ve kullandığım belgeyi de incelediği anlaşılmaktadır. H. W. Lowry yukarıda alıntısını verdiğim yazısında neden yalana dayalı bir kurgu yapma ihtiyacı hissetti acaba?

H. W. Lowry'nin gizledikleri ve yalana dayanan kurguları burada bitmiyor. Bu sempozyumun üzerinden bir ay geçmeden 4-5 Mayıs 2012'de, yani H. W. Lowry'nin hikâye ettiği şekliyle, kitabının Türkçe çevirisi henüz bitmiş, mizanpajla iki hafta daha uğraşırken, sehven eksik yazdığım belge numarasını düzeltip belgenin aslından ilgili satırların kopyasını da ekleyerek, Pranko Lazarat'ın vakfı ve türbesine dair yeni bir makaleyi Ankara Üniversitesi GAMER'de (Güneydoğu Avrupa Araştırmaları Dergisi) yayınladım. (Kılıç 2012: 87-99) Belge çok uzun bir Arapça vakfiye olduğundan tamamını yayınlamak zaten mümkün değildi. $H$. W. Lowry'nin sempozyumdaki konuşmasında belge numarasında sehven yaptığım hata üzerinden sahiplenme girişimi nedeniyle belge numarasında yaptığım hatamı gidermek amacıyla yayınlamıştım. O konuşmasında benim bilgi ve bulgularımı sahipleneceğine dair ciddi bir şüphe doğmuştu. Eğer belge ile birlikte ulaştığım özgün sonuçları da sahipleneceğini tahmin etseydim belki de tamamının kopyasını yayınlamayı akıl edebilirdim. Onun konuşmasından şüphelenmekte ne kadar haklı olduğumu üzülerek anladım. GAMER dergisi bizzat kendisine, saygıdeğer hocam Prof. Dr. Melek Delilbaşı tarafından 9-11 Mayıs 2012 tarihlerinde İstanbul'da düzenlenen "Balkanlarda Osmanlı Vakıfları ve Eserleri Uluslararası Sempozyumu'nda hediye edilmiştir. Bunu inkâr edeceğinden eminim ama aynı sempozyumda bu derginin daha pek çok katılımcıya hocam tarafindan hediye edildiğini unutmamasını tavsiye ederim. Ses kaydının peşinde yaptığım dedektifliği burada da yapmak zorunda kalmak istemiyorum. Bu makalemin onun planlarını bozduğu açıkça anlaşılıyor. Zira bu makaleyi verdiğimde henüz kitabının yayınlanmamış olduğunu hatırlatmalıyım. Bu süreci anlatırken H. W. Lowry'nin kendi kronolojisini hatırlarsak; Mayıs 2012'nin ilk haftasında kitabının Türkçe tercümesi tamamlanmış ve iki hafta daha mizanpaj üzerinden çalışmalar yapacaktır. 4-5 Mayıs 2012'de yayınlanan 9-10 Mayıs'ta H. W. Lowry'nin elinde olan GAMER makalemde de, daha önceki yayınlarımda ulaştığım sonuçları tekrarladım. Ancak bu kez belgenin ilgili kısmını resim olarak da 
ekledim ki ilk defa benim kullandığımı tescil ederek çalınmasına engel olayım. Aşağıdaki verdiğim tabloda bu makaledeki ilgili kısım da görülebilir.

Şimdi hikâyenin kronolojisini buraya kadar şu şekilde özetleyebilirim:

1-Mart 2011'de Doktora Tezim.

2-Aralık 2011'de Belleten'de yayınlanan makalem.

3- 4-5 Mayıs 2012'de GAMER dergisinde yayınlanan makalem.

$\mathrm{Bu}$ kronolojiye göre, kendi ifadesiyle Mayıs ayının ilk haftasında üç ayrı metnim bütün kullanıcılara açık ve ulaşılabilir durumda idi. Dolayısıyla, doktora tezimi görmediğini kabul etsem dahi, Belleten dergisindeki makalemi okumadığı iddiasının da yalan olduğunu yukarıda ispat ettim. Peki, GAMER dergisindeki makalem elinde olmasına rağmen görmezden gelmesinin sebebi nedir acaba? Bir bilim adamı, kitabının en orijinal ve yeni bir buluş olarak sunduğu kısmını yazarken, aynı şeylerden bahseden yayınları iki sebeple görmezden gelir. Ya bunları ciddiye almaz ve bahsetmeye değmez bulur veyahut bu intihal yaptığını gizlemek gibi daha farklı bir amacı vardır. Ciddiye almadığını söylemek mümkün değil çünkü nihayet Haziran 2012'de yayınladığı kitabına bir "Ek" yapacak kadar ciddiye aldığ 1 açıktır. Bu kitabında adeta "sonradan fark ettim ama benim yazdıklarımla Ayşegül'ün ilgisi yok" demektedir. Bunu yaparken bir yandan makalelerimi eleştirmeyi ve akademik yeterliliğimle alay edecek kadar kişilik katli teşebbüsünde bulunmayı da ihmal etmemektedir. Bu üslupla okuyucuyu aldatmaya ve benim çalışmalarımı önemsiz göstermeye çalıştığını inceleyenler anlayacaktır. Ancak burada da kendisiyle çelişkiye düşmektedir. Ne gariptir ki bir makalemi, yani 9-10 Mayıs 2012'de GAMER' de yayınlanan ve eline teslim edilen makalemi bu eleştirilerinden mahrum bırakmış adeta görmezden gelmiştir. Eğer sonradan gördüğü makalelerimi eleştirmek için kitabına bir ek yapma gereği duyduysa bu makalemi bir dipnotta dahi anma gereğini neden duymadı?

Burada, olayları takip etmekte zorlanan okuyucuya bazı hususları maddeler halinde hatırlatma gereği duyuyorum:

1. Yukarıda adı geçen bütün bu yayınlarımda H. W. Lowry’ye tek bir kelime hakaret veya intihal iddiası söz konusu değildir. Akademik eleştiriler dışında saldırı olarak algılanabilecek hiçbir ifadem de yoktur.

2. Yukarıdaki yayınlarımda kullandığım vakıf belgesi veya elindeki benzer bir vakıf belgesiyle ilgili Haziran 2012'de yayınladığı kitabına kadar Heath W. Lowry hiçbir yayınında söz etmemiştir.

3. Doktora tezim ve makalelerimden önce, H. W. Lowry’nin, Gazi Evrenos Bey'in etnik menşei konusundaki tezleri 2003 (Lowry 2003) ve 
2010 (Lowry-Erünsal: 2010: 124)'da yayınladığı eserlerinden farklı değildir. Yani, benim yukarıdaki yayınlarımda ifade ettiğim görüşlerimle hiçbir şekilde ortak yanı yoktur. Yukarıdaki yayınlarımda onun görüşlerini baştan aşağı eleştirdiğimi bilmektedir.

Bütün bu süreç boyunca, benim ne yazdığımdan, hangi kaynakları kullandığımdan ve görüşlerimden yayınlarım dolayısı ile haberdar olan $\mathrm{H}$. W. Lowry, 12 Haziran 2012'de Fourteenth Century Ottoman RealitiesOn Dördüncü Yüzyıl Osmanlı Gerçekleri adlı kitabını yayınladı. (Bu kitabın yayın tarihine dair 2014'te yayınlanan kitabımda yazdıklarım ve Heath W. Lowry'nin cevabına aşağıda yeniden değineceğim. Şimdilik durumu değiştirmese de kitabın künyesindeki tarihi esas alıyorum.) Kitap, İngilizce ve Türkçe olarak toplam $172+$ XII sayfadır. Kitapta 75 sayfa İngilizce, 74 sayfa Türkçe ana metin yer almaktadır. Bu kitabın 13 sayfalık ilk bölümünün İngilizce başlığı şudur: Codicil\# 1: The Ethnic Origins of the Evrenosoğlu Dynasty. Türkçe 13 sayfalık ilk bölümün başlığı ise şöyledir: Yeni Bulgu \# 1: Evrenosoğlu Hanedanının Etnik Kökenleri. Kitabın 7 sayfalık ek bölümünün başlığı İngilizce Appendix 1: Review of two Studies on Hâcı-Gâzi Evrenos/ Türkçe ek kısmı ise yine 7 sayfa olarak Ek- I: Hacı-Gazi Evrenos Hakkındaki İki Makalenin Tenkiti başlığı altında benim iki ayrı makalemi eleştirmiştir. (Lowry 2012a: 157-163) hissediyorum

$\mathrm{Bu}$ kitapla ilgili şu hatırlatmaları en başta yapma ihtiyacı

1- Benim Haziran 2012'den önce yayınladığım ve yukarıda detaylarını verdiğim hiçbir yayınıma kitabın Yeni Bulgu \# 1: Evrenosoğlu Hanedanının Etnik Kökenleri bölümünde atıfta bulunulmamıştır. Yani bütün bu bölüm kendi yeni bulgusu olarak yazılmıştır. Bu kitapta 8-9 Mayıs 2012 tarihinde elinde olan GAMER'de çıan makaleme hiç referans vermediği gibi hatta eleştiri bölümüne bile almayarak adeta görmezden gelmiştir.

$\mathrm{Bu}$ kitabında yayınlarımla ilgili "Ek" yazarak tenkit etme gerekçesini ve yaptığının meşruiyetini birkaç argümana dayandırmıştır:

a) Birkaç kilit noktada görüşlerimizin karşıt olduğu ve kendisinin görüşlerine yönelttiğim eleştirileri kişilik katli gibi yansıtarak cevap verdiğini ima ediyor. Lâkin şahsına yönelik hiçbir hakaret ve saygısızlık olmadığını okuyanlar görecektir. Tam aksine bu kitabında şahsımla alay eden, saldıran bir üslup kullandığı anlaşılacaktır.

b) Evrenos hanedanının etnik kökeni hakkında görüşlerimizin farklı olduğunu ifade ederek; "Referansı yanlış verilmiş İsa Bĕg vakfiyesinde Evrenos'un babasına verilen isim dışında, Kılıç’ın iki çalı̧̧masında da üzerinde yazdlğı konuyla ilgili bildiklerimizi geliștiren bir bilgi olduğunu söylemek zordur". Bu cümlesiyle bütün yayınlarımı önemsiz göstererek benim verdiğim "bildiklerimizi geliştirmeyen" bilgilerin neredeyse aynısını 
farklı cümlelerle kendi görüşü olarak yazdığını yayınlarımızı karşılaştıranlar açıkça göreceklerdir. Aşağıdaki tabloda okuyucuyu anlamasına yardımcı olmak amacıyla ilgili kısımları ekledim.

c) Kendi ifadesiyle "Kaynă̆g, önceki bölümde kullandığım kaynakla, yani 1456-1457 İsa Beğ vakfiyesiyle ayn belge gibi gözüküp, bu konudaki farklı görüşlerimiz de bir izah gerektirmektedir" diyerek belge numarasının referansını ilk makalemde hatalı vermeme dayanarak "aynı gibi gözüktüğünü” ama aynı olmadığını iddia etmektedir. Buradan sonra belge numarasını kendisinin daha doğru verdiğini ispata girişerek benim bu hatayı ya karıştırdığım için ya da kasıtlı olarak araştırmacıların bu belgeyi bulmaması için yaptığım gibi komik bir gerekçe ileri sürerek kendi ayıbını örtbas etmektedir. Şükür ki H.W. Lowry daha önce bulmuş olmasaymış, bu belgeyi bulmak imkânsız olacakmış! Esasında benim iddialarıma karşı tek savunması ve aynı zamanda suçlaması benim hatalı verdiğim ve sonra düzelttiğim belge numarasıdır. Aşağıda bu belgenin son derece kolay bulunabileceğini ve bulunması için pek çok ek bilgi verdiğimi şimdiye kadar yazdıklarımı yeterli görmeyenlere başka bir kanıt olarak sunacağım. Bu belgenin bulunmasının imkânsız olduğu ve bunu kasten sakladığım tamamen bir yalan ve manipülasyondan ibarettir.

Esasında daha anlaşılır olması bakımından, benim ve $\mathrm{H}$. W. Lowry'nin yazdıklarını bir tablo halinde ve kronolojik olarak göstermek en doğrusu. Belki yukarıda bahsettiğim ilgili yerleri ve H. W. Lowry'nin yazdıklarını karşılaştırmayı zor bulanlar olmuştur düşüncesiyle bir uzun bir tablo halinde sunmak istedim. Ancak yazıyı fazla uzatacağından burada daha kısaltılmış versiyonunu eklemeyi uygun buldum. Tabloda önce benim konuyla ilgili yazdıklarımı, daha sonra H.W. Lowry;'nin yazdıklarımın incelenmesini tavsiye ediyorum. ${ }^{3}$

3 Bu yazıda sözü edilen bütün yayınlarımın tam metinleri elektronik olarak (pdf formatında) www.academia.edu sayfamda ulaşılabilir durumdadır. 
1-Gazi Evrenos Bey-Doktora Tezi- MART 2011

2- Evrenos Bey'in Kökeni Hakkında Tartışmalar ve Yeni Bir Değerlendirme, BELLETEN, c. LXXV, Say1 274, (Aralık) Ankara 2011, s. 745-768. ARALIK 2011

3- Evrenos Bey'in Babası Pranko Lazarat'ın (Pranko İsa) Vakfi ve Türbesi”, Güneydoğu Avrupa Çalışmalart Uygulama ve Araştırma Merkezi Dergisi, GAMER, c.I, S. 1, Ankara (4-5 Mayıs 2012), s. 87-99

Alt başlık: Pranko Lazarat ve Avraniz/Evraniz: Prankı İsa ve Evrenos'un Adına Dair Yeni Bulgular (Doktora Tezi, Mart 2011)

Alt başık: -Prankı İsa ve Evrenos'un Adına Dair Yeni Bulgular- (Belleten,(Aralık 2011, s. 759)

Alt başlık: Pranko Lazarat'ın (İsa Bey'in) Vakfi (GAMER, 4-5 Mayıs 2012)

Doktora Tezi Mart 2011, s. 59-60:

“... İsa Bey’in bugüne kadar tespit edilmeyen farklı bir ismiyle de karşı karşıyayız. İsa Bey için kullanılan bu isim, aynı adı taşıyan torununun yani Evrenos Bey'in oğlu İsa Bey'in H. 861 (1457) tarihli Selanik vakfiyesinde yer almaktadır. Bu vakfiyede dikkati çeken ilk şey, Evrenos'un baba adı olarak bilinen ve her belgede karşımıza çıkan "İsa Bey" adının kaydedilmemiş olmasıdır. Belgede Evrenos Bey'in babasının ismi "Pranko Lazarat ( يرانقو (لازارت " olarak şimdiye kadar karşılaşmadığımız bir şekilde geçmektedir. İlk defa rastlanılan bu bilginin, şimdiye kadar yapılan Evrenos Bey ve babasının kökenine dair tartışmalar açısından önemi așikardır. $\mathrm{Bu}$ nedenle bașka bir belgede bu bilgiyi teyid edebilecek kanıtlara ulaşmak önemlidir. $\mathrm{Bu}$ bağlamda yaptığımız araștırmalarda ilginç bir şekilde bu Lazarat ismine 1530 tarihli Muhasebe-i Vilâyet-i Rumili defterinde ve başka kayıtlarda da rastliyoruz. $\mathrm{Bu}$ defterde Serfiçe (Servia) kazasına bağlı bir köy adı olarak geçen Lazarat adının kullanımı, aynı isimle bir karyenin var oluşu nedeniyle tesadüfî bir okuma olmadığının kanıtı olarak sayılabilir. Ayrıca bu kayıtta İsa adının bulunmaması da oldukça düşündürücüdür. Yukarıda bahsettiğimiz belgelerde Branko/Prankı lakabı farklı telaffuzlarla geçse de lakabın ardından mutlaka İsa Bey olarak kaydedilmiş olduğunu
Fourteenth Century Ottoman Realities, In Search of Hâcı- Gâzî Evrenos- Ondördüncü Yüzyıl Osmanlı Gerçekleri, Hacı-Gazi Evrenos'un İzinde, Bahçeşehir Üniversitesi Yayınları, İstanbul

HAZIRAN 2012
Codicil\#1: The Ethnic Origin of the Evrenosoğlu Dynasty (s.3)/Yeni Bulgu \#1: Evrenosoğlu Hanedanının Etnik Kökenleri (s. 89)

\section{Haziran 2012}

1) Evrenos'un kökenlerine dair kendi eski teorilerinden bahsederken “...Evrenos'un Karesi kökenli, yani kuzeybatı Anadolulu bir Türk olduğuna dair yaygın açıklamayı reddetmiştim. Bunun yerine, Balkanlarda doğup büyüdüğü ve Prangi İsa isimli bir Katalan paralı askerinin oğlu olabileceğini öne sürmüştüm."

2) "Yakın bir zamanda, Evrenos hanedanının üyeleri tarafindan kurulan vakıflariçin kaleme alınan vakfiyeleri ararken, İstanbul Başbakanlık arşivinde muhafaza edilen bir kopyaya denk geldim. .... Belgenin orjinali hicri 861'de yani 29 Kasım 1456 ile 18 Kasım 1457 arasında kaleme alınmıştır. ....ve gerçek olduğu 25 Cumadelûlâ 1320'de (29 Eylül 1902), Selânik Evkaf Dairesi tarafindan teyit edilmiştir. (s. 89-90)

3) ...Burada ilgi çekici olan vakıf sahibinin soy ağaciyla ilgili bilgilerdir. Şöyle yazmaktadır: "Branko/Pranko Lazart oğlu büyük emir, merhum, şöhretli Evraniz/Avraniz oğlu İsa Beğ...” (s. 90)

4) İsa Beğ' in vakfiyesindeki bu isimlerin üç önemli sonucu vardır: a) Bugün Evrenos olarak bildiğimiz için alternatif bir 15 . Yüzyıl versiyonu sunmaktadır; b) Evrenos'un babasını Branko/Pranko Lazart olarak listeleyerek ismin şimdiye kadar hiç bilinmeyen bir versiyonunu sağlamaktadır ve c) son olarak, Evrenosoğlu hanedanının kurucusunun 
biliyoruz. Burada ise sadece Pranko Lazarat olarak kaydedilmiştir. Ayrıca aynı belgede Evrenos Bey'in isminin ilk defa “Evraniz/Avraniz” [ اورانيز] şeklinde karşımıza çıkması da ilginçtir. Bu da bize yukarıda Bizans kaynaklarında geçen Evrenos Bey isimlerini hatırlatmaktadır. Belki de ismin doğru telaffuzunun Avranezis (A $\beta \rho \alpha v \varepsilon ́ \zeta \eta \zeta)$ ya da Vranezis (B $\rho \alpha v \varepsilon ́ \zeta \eta \zeta)$ şeklinde olabileceği ihtimalini bize düşündürmektedir. "

\section{Doktora Tezi Mart 2011, s. 60-61:}

“... Diğer yandan, bu belgenin orijinal olduğuna dair bazı işaretler söz konusudur. Evrenos'un oğlu Gazi İsa Bey'e ait 1457 tarihli Arapça vakfiyenin H. 1320 (1902-1903) tarihinde aslından kopya edilmiş bir suret olduğu anlaşılmaktadır. Çok geç tarihli bir suret olsa da belgenin orijinal olduğunu düşünmemizin sebebi, belgenin H. 861 (145657) tarihiyle son bulmasıdır. $\mathrm{Bu}$ tarihten sonrasına ait herhangi bir bilgi eklenmemiştir. Burada dikkati çeken en önemli şeylerden biri, kopyalayan kâtibin herhangi bir derkenar eklemeden, sadece bu tarihi taşıyan yani tahminimizce bir nevi tecdid edildiğini gösteren bir pul yapıştırmış olmasıdır. Kâtibin belgeye herhangi bir müdahalesi görülmemektedir. Öte yandan, dikkat çeken diğer bir nokta, şimdiye kadar bütün Osmanlica belgelerde Evrenos olarak gördügümüz bu ismin kâtip tarafindan neden farklı yazıldığ 1 sorusudur. Kâtibin, belgeyi kopyaladığı tarihte ünü yüzyıllardır devam eden Evrenos'un adını yanlış yazma ihtimali çok düşük olmalıdır. Saydığımız sebeplerden ötürü orijinal sayabileceğimiz bu belgenin bizim açımızdan diğer bir önemi ise Osmanlı kronikleri gibi hanedan tarihlerinden farklı olarak Selanik'te yani vakfin bulunduğu yerde kaydedilmiş olmasıdır. Ayrıca bu kaynaklardan daha önce 1456-57 gibi erken bir tarihte, Osmanlı kroniklerinin henüz yazılmadığı bir döneme ait nadir bir belge olarak daha farklı yorumlara kapı açma ihtimalidir.

\section{Belleten, s. 760 (Aralık 2011)}

"Belgede Evrenos Bey'in babasının ismi 'Pranko Lazarat olarak şimdiye kadar karşılaşmadığımız bir şekilde geçmektedir. İlk defa rastlanılan bu bilginin, şimdiye kadar yapılan Evrenos Bey ve babasının kökenine dair tartışmalar açısından önemi aşikârdır."

Belleten, s. 761 (Aralık 2011)

"Ayrıca aynı belgede Evrenos Bey'in adının ilk defa "Evraniz/Avraniz" şeklinde karşımıza etnik kökenlerine dair bir ipucu

vermektedir. (s. 91) (Haziran 2012)

5) “Esas konuya gelirsek, Evrenos'un babasının isminin 1456-1457 vafiyesinde yazılış şekli, ailenin etnik kökenlerini belirlemek açsından ilgi çekicidir. $\mathrm{Bu}$ belgede İsa Beğ (...) olarak değil, Brango/Prango Lazart (...) olarak yazılmıştır. Bugüne kadar ki belgeler arasında Evrenos'un babasının ismini Lazart olarak aktaran tek örnek olsa da, erken 16. Yüzyll tarihli bir tahrir defterinde Branki (...) Îsâ Beğ olarak yazılması, Branko/Pranko ismini teyit etmektedir.” s. 93

6) “ 'Branko' ismine gelince, bugün Slavlar arasında hâlâ kullanılan bir isimdir (güncel bir örnek olarak Branko Cicenkovski verilebilir, 2004 yılında yakında kurulan Makedonya Cumhuriyeti'nin ikinci Cumhurbaşkanı olarak seçilmiştir). 'Branko' ismi 'Branimir ve/veya 'Branislav' isimli erkekler için kullanılan Slavca bir kisaltmadır. (s. 94)

7) "Ĕ̆er bu tespit doğruysa, Evrenosoğulları olarak bilinen hanedanın EvranizAvraniz isimli Sirp bir mühtedi tarafindan kurulduğunu, onun da, Müslüman olduktan sonra Branko/Pranko İsa ismini alan Branimir/Branislav Lazart isimli bir Sırp savaşçının oğlu olduğunu göstermektedir.” s. 96

8) ... “ 'İsa' bir Müslüman ismi olup, Evrenos (mevcut çalışmadaki hipotez geçerli olduğu sürece) ise Slavca kökenli bir ismin değiştirilmiş versiyonudur." s.99

9) Tablo I, geç 14. Yüzyıl ve erken 15. Yüzyıl Bizans, Venedik ve Osmanlı kaynaklarında (1387-1417) bulunan Evrenos ismi varyantlarının dökümünü sunmaktadır. Bu varyant dökümünde ağır bir şekilde eleştirdiği Evrenos'un İmajı makalemizdeki verileri dipnotsuz kullanarak oluşturmuştur. Hazır tespit edilmiş arşiv belgesi ve Bizans-Osmanlı kaynağ1 verilerinden 3.5 ayda kitap yazmak oldukça manidardır. s. 91-93

10) İsmin çağdaş varyantları ile Doukas'ın 15. Yüzyıl Bizans kroniğinde bulunan versiyonu (Avrenezis); ve PseudoSphrantzes'in geç 16. Yüzy1l eserindeki versiyonu (Vrenezis) karşıllaştırılınca, 
çıkması da ilginçtir. $\mathrm{Bu}$ da bize Bizans kaynaklarında geçen Evrenos isminin farklı yazım şekillerini (Lowry'nin tabiriyle varyantlarını) hatırlatmaktadır. Belki de isminin doğru telaffuzunun Avranezis ya da Vranezis şeklinde olabileceği ihtimalini düşündürmektedir. Ayrıca Evrenos Bey’in 1417 tarihli mezar kitabesinde ad1 Evrenoz/Evrenuz şeklinde kaydedilmiş idi. Aslında Türkçe okuma kolaylığı sağlayan ilk sesli harf çıkarıldığı zaman yine Bizans kaynaklarındakine ve vakfiyede tespit ettiğimiz isme benzer şekilde "Vranez/Vraniz adı ile karşılaşmaktayız.

\section{Branko adına dair yorum:}

$\mathrm{Bu}$ ismin hemen bize Balkan Slavları arasında yaygın olan Lazar Brankoviç veya modern Sırp isimlerinde de görülen Branko Lazar'1 hatırlattığını belirtmeliyiz. Kanaatimizce 'Frenk' kelimesinden hareketle ortaya çıkan varsayımlardan [H. Lowry'nin görüşü] daha az zorlama gerektiren bir çıkarımdır. Üstelik bu varsayımı destekleyen bazı işaretler vardır. Eğer yukarıda bahsettiğimiz gibi bugün de kullanılan Branko/Pranko Lazar ismini bir işaret saymazsak, tarihi metinlere baktığımızda Brankoviç adının Pranko olarak yazıldığını görürüz. Örneğin Bizans Klsa Kronikleri'nden birinde kronik yazarı Lazar Brankoviç'in babası ve Stefan Lazareviç'in rakibi olan Vuk Brankoviç'in Vounko Pranko olarak yazıldığı görülmektedir. Bu kanıtlar en azından bize Pranko kelimesinin kökenine dair bir fikir verir.

Ayrıca aynı belgede Evrenos Bey'in adının ilk defa “Evraniz/Avraniz" [اورانيز [şeklinde karşımıza çıkması da ilginçtir. $\mathrm{Bu}$ da bize Bizans kaynaklarında geçen Evrenos isminin farklı yazım şekillerini hatırlatmaktadır. Belki de ismin doğru telaffuzunun Avranezis

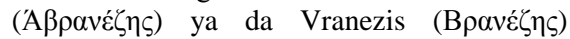
şeklinde olabileceği ihtimalini düşündürmektedir. Ayrıca Evrenos Bey'in 1417 tarihli mezar kitabesinde ad1 Evrenoz/Evrenuz (اورنز) şeklinde kaydedilmiş idi. Aslında Türkçe okuma kolaylığı sağlayan ilk sesli harf çıkarıldığı zaman yine Bizans kaynaklarındakine ve vakfiyede tespit ettiğimiz isme benzer şekilde "Vranez/Vraniz" ( ورنز) adı ile karşıllaşmaktayız. Ayrıca şu sayfaları karşılaştırınız:

Doktora Tezi Mart 2011, s. 58-59:

Belleten, s. 757, 760, 762, 763 (Aralık 2011);

GAMER, s. 89-90. (4-5 Mayıs 2012) yaşadığı süre ve sonrasında (en azından 16. Yüzyıla kadar), meşhur Uç Beyi'nin Evrenos olarak değil de 1417 mezar taşındaki imlayla benzer şekilde Vranezis/Evreniz/Avraniz/Evrenüz olarak bilindiği görülmektedir.

11) "Lazarat ismi ile, Mora yarımadasının Balya-badra bölgesinde bulunan ve 1530 tarihli bir Osmanlı tahrir defterinde Lazart olarak yazılan köyün isim benzerliği, bu ismin kökenine dair muhtemel bir açıklamaya işaret etmektedir. Aynı köy, hicri 920-928 y1lları arasında, yani 1514-1522 yıllarında kaleme alınan ikinci bir defterde listelenmektedir. Bu defterde köyün ismi 'Lazart' olarak değil 'Lazarat' olarak yazılmıştır, bu yer ismi bugün Güney Arnavutluk'un Adriyatik Denizi kıyısındaki küçük bir köyünde varlığını sürdürmektedir.” s. 94

12) "Bugüne kadarki belgeler arasında Evrenos'un baba ismini Lazart olarak aktaran tek örnek olsa da, erken 16. Yüzyıl tarihli bir tahrir defterinde Branki/Pranki İsâ Beğ olarak yazılması, Branko/Pranko ismini teyit etmektedir. İlk olarak Ömer Lütfi Barkan tarafından yaklaşık altmış yıl sene evvel keşfedilen ve yayımlanan bu belge, Evrenos'un babasının türbesinin olduğu yerde kurduğu bir zaviyeden bahsetmektedir." s. 93-94. 
Görüldüğü gibi Evrenos Bey'in babası hakkında hem kullandığım belge hem de yaptığım yorumlarla $\mathrm{H}$. W. Lowry'nin "Yeni Bulgu" olarak yazdıkları arasında kendisinin iddia ettiği gibi farklı görüşler söz konusu değildir. Benim görüşlerimin farklı cümlelerle yeniden sunumundan başka bir şey olduğu söylenemez. Gelelim H.W. Lowry'nin bütün bulgularını dayandırdığı ve benimkinden farklı olduğunu iddia etse de kendisinin dahi inanmadığı anlaşılan, vakıf belgesinin numarası ve bu belgeyi nasıl bulduğunu izah etmeye çalıştığı ifadelerine. Hatırlanacağı gibi kendi cümleleriyle bu durumu şöyle izah etmektedir: "Kaynağı, önceki bölümde kullandığım kaynakla, yani 1456-1457 İsa Beğ vakfiyesiyle aynı belge gibi gözüküp, bu konudaki farklı görüşlerimiz de bir izah gerektirmektedir" (Lowry 2014: 482) Ardından benim bu belgeyi kasten sakladığımı iddia ederek, kendi bulduğu belgenin benim kullandığıma benzediğini ancak sakladığım için bu belgeye ulaşamadığını anlatmaktadır. $\mathrm{Bu}$ izah, H. W. Lowry'nin belgeyi sahiplenirken kullandığ argüman olarak karşımıza çıkıyor. Okuyucuyu zorlamamak için H. W. Lowry'nin dolambaçlı olarak sayfalar dolusu ifade ettiği bu gerekçeleri şöyle basitleştirebiliriz:

"Ben çok önemli bir belge buldum ve bu belge kitabımdaki Yeni Bulgu olarak yazdı̆ğm bölüme esas olmuştur. Bu belgeyle Evrenos Gazi'nin babasının kökeni üzerine keşif yaptım. Ancak Ayşegül Kılıç aynı keşfi yaptığın söylüyor. Fakat kullandığı belgenin benim bulduğum belgeyle aynı olmadığını düşünüyorum. Çünkü belge numarasını saklamak için belge numaralarını kasten yanlıs vermiş. Dolaylsıly la bu belgeyi keşif sürecinde onun yazdlğg tez ve makalelerin hiçbir payı yoktur. Ben zaten Evrenos Bey üzerine çalıştığım, üstelik ünlü bir tarihçi olduğum için bu belgeyi bulmam gayet doğaldır. Hatta yaptığımız yorumlar birbirine benzese bile sakın ola ki onun yorumlarının orijinal olduğunu düşünmeyin. Bunu sıradan bir taşralı akademisyen yapamaz, sadece benim gibi ünlü bir tarihçinin zekâ ürünü olmalıdır." Esasında H. W. Lowry'nin bütün söylediklerinin Türkçe meali yukarıda yazdığım gibidir. Sadece bunu kendine özgü bir üslup ve metodoloji ile sunarak yanıltmaya çalışmaktadır. Dolayısıyla H. W. Lowry'nin en temel dayanağı olan şey sik sik tekrarladığ durduğu gibi benim belge numarasını kasten sakladığım ve bilim dünyasının bu belgeye ulaşmasını engellediğim suçlamasıdır. Fakat bir doktora tezinin en önemli parçası ve makalesinin temel dayanağı olan bir belgeyi hangi aklı evvel doktora öğrencisi saklar ki? Aksine bu belgeyi sahiplenmek için bir an önce yayınlamak istemez mi? Zaten bu belge üzerinden yapılacak bütün analizleri yazmış ve belgeden uzun uzun bahseden bir akademisyen bu belgeye kimsenin ulaşamayacağını nasıl düşünür ki? H. W. Lowry, sanırım Türkiye’deki akademisyenlerin zekâ seviyesini fazla küçümsüyor. Veyahut Türkiye'de meydan ona hep boş olduğu için ona gösterilen teveccühü kötüye 
kullanıyor. Şimdi gelelim bu belge saklama meselesine. Hem Belleten'deki makalemde verdiğim bilgilerden hem de GAMER'deki makalemde de izah ettiğim gibi, bu belge arşiv kataloğunda 'genel sıra no', 'kronolojik sıra' ve 'vakıf adlarına göre' olmak üzere üç ayrı şekilde ve tek cilt olarak hazırlandığından" vakfiyeye ulaşmak oldukça kolaydır. Yani numara dışında İsa Beğ vakfiyesi ya da arşivde böyle kayıtlı olduğu için Selanik vakfiyesi olarak da herkesin kolaylıkla ulaşabileceği bilgilerdir. Dikkatli okuyucular, yayınlarımda bu belgeden bahsederken sadece dipnotta belge numarasını vermediğimi, bu belgeyi metin içinde tarif ettiğimi, tarihini yazdığımı görmüşlerdir. Sanırım beni küçük düşürmenin ve bulgularımı sahiplenmenin bir yolu olarak bu belgeyi kasten sakladığımı iddia etmek, H.W. Lowry'nin kıvrak zekâsıyla yapacağı manipülasyonun en önemli "yeni bulgusu" olmuştur. Bu belgeyi gizlemenin ve belge hakkında yazdıklarımdan sonra insanları yanlış yönlendirmenin imkânsızlığını Osmanlı arşivlerinde araştırma yapmayı bilen herkesin anlayacağına eminim. Yine de bu belgenin numara kullanmadan kaç farklı şekilde aranıp bulunabildiğini aşağıdaki örneklerle gösterme ihtiyacı hissediyorum. Aşağıda Başbakanlık Devlet Arşivleri Genel Müdürlüğü'nün internet sitesinden yapılacak basit bir araştırma ile bu belgeye nasıl ulaşılabileceğini anahtar kelimeleri vererek göstereceğim. $\mathrm{Bu}$ aramaların ekran görüntülerini yazıyı uzatmamak için eklemiyorum. Kısacası, ben bu belgeyi kasten saklamış olsam dahi yayınlarımda verdiğim bilgilerden belgeye ulaşmanın pek çok yolu olduğunu rahatlıkla söyleyebilirim. Merak edenler Başbakanlık Devlet Arşivleri internet sitesinden aşağıdaki anahtar kelimeleri kullanarak değişik versiyonları deneyerek bu belgeye ulaşabilirler:

Fon Adı: Tümü ve Aranacak İfade: "Gazi İsa Bey Selanik", Fon Adı: Evkaf Aranacak İfade: "Selanik", Fon Adı: Tümü, Aranacak İfade: "Selanik İsa Bey" Fon Adı: Tümü, Tarih: H. 861 ve "Evrenos" Fon Adı: Evkaf Aranacak İfade: "Selanik suret” Fon Adr: Evkaf Aranacak İfade: "İsa Bey"

Görüldüğü gibi bilim camiasından saklamakla suçlandığım belge rahatlıkla ve ilk sayfalarda karşımıza çıkmaktadır. Bu versiyonların dışında farklı kombinasyonlarla ve birkaç belge incelemesi ile ulaşılmasını kolaylaştıracak pek çok bilginin benim yayınlarımda verildiğini, sadece belge numarasındaki sıralamada hata yaptığımı bütün okuyucular anlayacaktır. Bütün savunmasını, benim bu belgeyi kasten sakladığım ve kendisinin zaten benden önce bulduğu iddiasına dayandıran $\mathrm{H}$. W. Lowry'nin belgeye kolaylıkla ulaşabildiğini tahmin etmek zor olmasa gerektir.

Söz konusu bu vakfiyenin isimlendirilmesi konusuna gelince; belgeyi bilim dünyasından kasten gizlemekle suçlayan $\mathrm{H}$. W. Lowry, vakfiyenin adını kasten yanlış olarak "Selanik Vakfiyesi" olarak 
isimlendirdiğimi yazmaktadır. Belgenin adı Başbakanlık Osmanlı Arşivi'nde "Gazi İsa Bey (Selanik-Suret)" olarak kayıtlıdır ki numara dışında bu adla da yani "Selanik Vakfiyesi”" olarak da isteyen herkesin kolaylıkla ulaşabildiğini yukarıda gösterdim. Bu isimlendirme tarafıma ait değildir. Beni suçlayarak belirttiği gibi bu vakfın asıl yerinin Yenice-i Vardar vakıflarından olduğu için vakfiyede "kasaba-i Vardar Yenicesi" olarak kayıtlı olduğu doğrudur. Elbette, Yenice-i Vardar'ın vakfiyede geçtiği şekliyle "Mahrûse-i Selanik”e bağlı olmasından dolayı Gazi İsa Bey (Selanik-Suret) olarak kaydedilmiştir. H. W. Lowry'nin iddia ettiği gibi Yenice-i Vardar Vakfiyesi olarak isimlendirmek katalogda Selanik göründüğü için beni suçladığının aksine arşive gidenlerin tespitini zorlaştıracaktır. Dolayısıyla, H. W. Lowry'nin benim cehaletimi gösterip hatalarımı çoğaltarak yazdıklarımı değersizleştirme gayreti burada da ortaya çıkmaktadır. Eğer önerdiği gibi yapsaydım ve belge adını Yenice-i Vardar Vakfiyesi olarak isimlendirseydim asıl o zaman bu belgeyi bulmak daha zor hale gelecek ve kendisinin de belgeyi bulması zorlaşacaktı. Esasında bu tercihi yaptığım için teşekkür etmeli diye düşünüyorum. Burada kendisine bir soru da sormalıyım: 'Acaba belgeyi Yenice-i Vardar Vakfiyesi olarak mı aradınız, tesadüfen mi buldunuz yoksa benim çalışmalarım dolayısıyla mı haberiniz oldu? Okuyuculara yukarıdaki arşiv sitesine Yenice-i Vardar Vakfiyesi olarak yazarak belgeyi bulmaya çalışmalarını tavsiye ediyorum. Acaba aynı belgeye hızlıca ulaşmak mümkün oluyor mu?

\section{H.W. Lowry'nin diğer eleştirileri ve iddialarına cevaplar:}

Buraya kadar H. W. Lowry'ye yönelik iddialarım ve onun bu iddialarıma yönelik kurgusal senaryosunu açığa çıkarmak amacıyla sadece meselenin özü üzerinde durmak istedim. Aksi takdirde, H.W. Lowry’nin amaçladığ1 gibi okuyucuların gözünden asıl meseleyi kaçırmasına yardım etmiş olacaktım. Meselenin özüyle ilgili gerçek bir cevabı olmadığı için genellikle yaptığı gibi, benim yaptığım hatalardan hareketle bulgularımı önemsizleştirerek sahiplenme, kişiliğim ve eğitimim üzerine küçümseyici üslubu, kibirli ve aşağılayıcı tavrıyla kendi popülaritesini ve akademik gücünü kullanma konusunda maharetli olduğunu itiraf etmeliyim. Bu nedenlerle, asıl konu ile cevap verilmesi gereken tali meseleleri burada ayırmayı uygun gördüm. Şimdi şahsıma ve yazdıklarıma yönelik saldırılarına maddeler halinde yanıt vereceğim.

1- H.W. Lowry vakfiyenin okunmasında benim hata yaptığımı ve "şehir" olarak okunması gereken kelimeyi "şehid" olarak okuduğumu şu alaylı cümlelerle iddia etmektedir: "on senedir Evrenos üzerine çalışan birinin bu kısmı nasıl yanlış okuduğunu açıklamak zordur. Kesin olan bir şey var ki, Evrenos "şehid" olmadl. Savaşta ölmek bir yana, son derece geç bir yaşta (görünüşe bakılırsa eceliyle) vefat etmiş ve 17 Kasım 1417 Çarşamba 
günü Yenice-i Vardar'da defnedilmiştir. Kılıç, bu gerçeğin tamamen farkında olsa da, anlaşıldığı kadarıyla İslam adına savaşırken hayatın kaybedenlere verilen bu unvanı taşımasında bir tutarsızlık görmemiştir." (Lowry 2014: 486-487) Alayc1 bir üslupla neredeyse bir sayfa boyunca benim ne kadar cahil olduğumu göstermeye çalışıyor. Öncelikle, kendisi gibi 16 yıldır Evrenos üzerine çalışan birinin bu kısmı dile getirmesi oldukça ilginçtir. Ömrünü fetihlere adamış, hayatı akınlarda geçmiş bir Osmanlı beyinin "şehid" unvanını alması için İslam adına savaşta ölmesine gerek olmadığını bilmesi esasen kendisinden beklenirdi. Kaldı ki Evrenos'un vakıflarını bile müstesna vakıf olarak kabul eden Osmanlılar, bu Balkan fatihine gereken önemi vermişlerdir. Ayrıca, bana saldırmak ve alay etmek için böyle detaylarla uğraşırken kendi tutarsızlığını da gözden kaçırmıştır; beni şehid olarak okumakla suçlayan H. W. Lowry'nin, Evrenos Bey'in 1417 tarihli mezar kitabesindeki ifadeyi kendisinin de "şehid" olarak okuduğunu ve bu şekilde defalarca yayınladığını hatırlatmak isterim (LowryErünsal 2010: 89). Şehitliğin kitabî tanımını elbette ben de biliyorum. Ancak Evrenos Bey gibi bir şahsiyete bu unvanın layık görüldüğünü anlamak zor olmasa gerek. Dolayısıyla mezar kitabesinde Evrenos'u şehid olarak okuduğu halde şehitliğini kabul etmediğini mi iddia etmem gerekiyor? Ya da bu kitabeyi okumadığını veya başkasına okutup dikkat etmeden yayınladığını mı? H. W. Lowry'nin üslubu ile davranırsam kendisini sadece bu nedenle sürekli aşağılamam ve kötü niyetli olmakla suçlamam gerekirdi. Sadece bu şehid-şehir meselesinde yanıldığını söylemekle yetinmeyi tercih ediyorum. Burada merhum Gazi Evrenos'a şehid unvanını yeniden iade ederek hatayı farklı örneklerle de düzeltmek isterim:

Kad mâte ve nukile min dâri'l-fenâ ilâ dâri'l-bekâ el-merhûm

El-mağfûr es-sa'îd eş-şehîd melikü 'l-guzât ve'l-mücahidîn (Demetriades

1976: 331; Krş. Lowry-Erünsal 2010: 89)

Ayrıca konuyu çalışan biri olarak Evrenos Bey'in şehid olarak geçtiği diğer bazı örnekler göstermek isterim. XVI. yüzyıla ait, $H$. W.Lowry'nin de eserlerinde kullandığı Muhâsebe-i Vilâyet-i Rumili Defteri'nde de Evrenos Bey şehîd olarak anılmaktadır:

"Vakf-ı sa'îü'l-hayât ve şehîdü'l-memât merhûm Gâzi Evrenos Beğ..." "4 veya

“Sa'îdü’l-hayât ve şehîdü'l-memât merhûm ve mağfûrün leh Evrenos Bey",5

4167 Numaralı Muhâsebe-i Vilâyet-i Rûm-ili Defteri, (937/1530) I, Dizin ve Tıpkıbasım, Başbakanlık Devlet Arşivleri Genel Müdürlüğü Osmanlı Arşivi Daire Başkanlığı Yay., No: 65, Ankara 2003, v. 198.

5 BOA, Şura-yı Devlet Evrakı, No: 11/22. 
Osmanlıca'da ' $d$ ' ve ' $r$ ' harflerinin el yazısında benzerliği nedeniyle bu örneklerin de şehir okunabileceğini iddia edilebilir. Ancak Rumeli Defteri'nde metnin devamında babasını şehîd olarak kaydettiğinden ve bu kabul gören bir bilgi olduğundan dolayı iki kelimenin yazılış şekillerini karşılaştırmanızı salık veririm ${ }^{6}$. Daha fazla örnekler de verilebilir. Zannederim ki yukarıdaki ve aşağıdaki örnekleri gördüğünde bu konuda yeniden israrc1 olmayacaktır. Eğer mezar taşında kendisinin de daha önce okuduğu gibi "şehid" olarak yazıldığını hatırlasaydı, bana hakaret edemeyeceğinden eminim. Yapılanın sadece kelime oyunlarıla okuyucuyu asıl meseleden uzaklaştırmak ve yaptı̆̆ını meşrulaştırarak benim ne kadar yetersiz olduğumu gösterme gayreti olduğu anlaşılmaktadır.

2- Tüm bunların dışında tarafıma H. W. Lowry'nin “yazarın meslektaşlarının eserlerini (bilhassa benim ve ortak yazarım İsmail E. Erünsal'ın) izin almadan, umursamazca kullanmak gibi bir alışkanlığı var", gibi ağır bir suçlamada bulunmaktadır. Kendi kitabından kullandığım iki fotoğraf üzerine bu iddiada bulunmaktadır. Türkçe'de "alışkanlık" kelimesi sık sık yapılan eylemler için kullanılmaktadır. Oysa dipnotsuz hiçbir bilgi kullanmadığım gibi adı geçen 2 fotoğrafı da dipnot vererek kullandım. Tesadüfen buldum veya ben çektim gibi bir bahane ileri sürmedim. Naklen şu eserdendir diyerek alıntı verdiğimi görmesine rağmen bunu anlamsız yere genç bir meslektaşının itibarını bu kadar kolay ve basitçe karalamaya çalışmak için kullanmak basit ifadesiyle kabalıktır. Ancak kendisi ve Sayın Erünsal'ın birlikte yayınladığı kitaptan temin ettiğim ve yine dipnotu ile birlikte kullandığım bahsedilen iki fotoğraf konusunda hatamı kabul ediyorum. Telif haklarının alınması veya çıkarılması konusunda yayınevi ile aramızdaki iletişimsizlik nedeniyle bu yazısındaki tek haklı eleştirisini kabul ediyorum ve bu konuda açıkça hukuki haklarını istediği zaman kullanabileceğinizi beyan ediyorum. Ancak bu bir 'intihal' değil sadece fotoğrafların izinsiz kullanımıdır. Yani kaynakça göstermeden sahiplendiğim fotoğraflar değil izin almayı ihmal ederek ama kaynağını göstererek kullandığım bir materyaldir. Ayrıca konumuzla ve benim iddialarımla da ilgisi olmayan bu mesele bana saldırmak amacıyla kusur aramaktan başka bir şey değildir

3- H. W. Lowry'nin diğer bir iddiası ise kitabında kullandığı Evrenos Bey'in zırhı ve Kur'an-1 Kerim fotoğraflarını izin almadan kullandığıma dairdir. $\mathrm{Bu}$ fotoğraflar konusunda beni suçladığı gibi kendisinden izin almamı gerektiren bir durum söz konusu değildir. Çünkü, H. Lowry söz konusu kitabında ilgili resimleri yayınlamadan önce benim 2 yıldır yayınevinde bekleyen kitabımın içeriğinde yer almaktaydı. Aşağıda 
Genelkurmay Başkanlığı'ndan aldığım resmi izin evrakı sanıyorum konuya yeterince açıklık getirecektir. Aralık 2011 tarihinde ben bu izni aldığımda $\mathrm{H}$. W. Lowry henüz kitabını yazmaya dahi başlamamıştı. Bu nedenle kitabından 2 yıl önce iznini aldığım resimleri yayınlamamın "asla yapılmaması gereken gayr-ı ahlaki bir durum" olduğunu belirtirken bir kez daha düşünmesini tavsiye ediyor ve özür dilemesini bekliyorum.

\section{Genelkurmay Başkanlığı'nın resmi izin yazısı:}
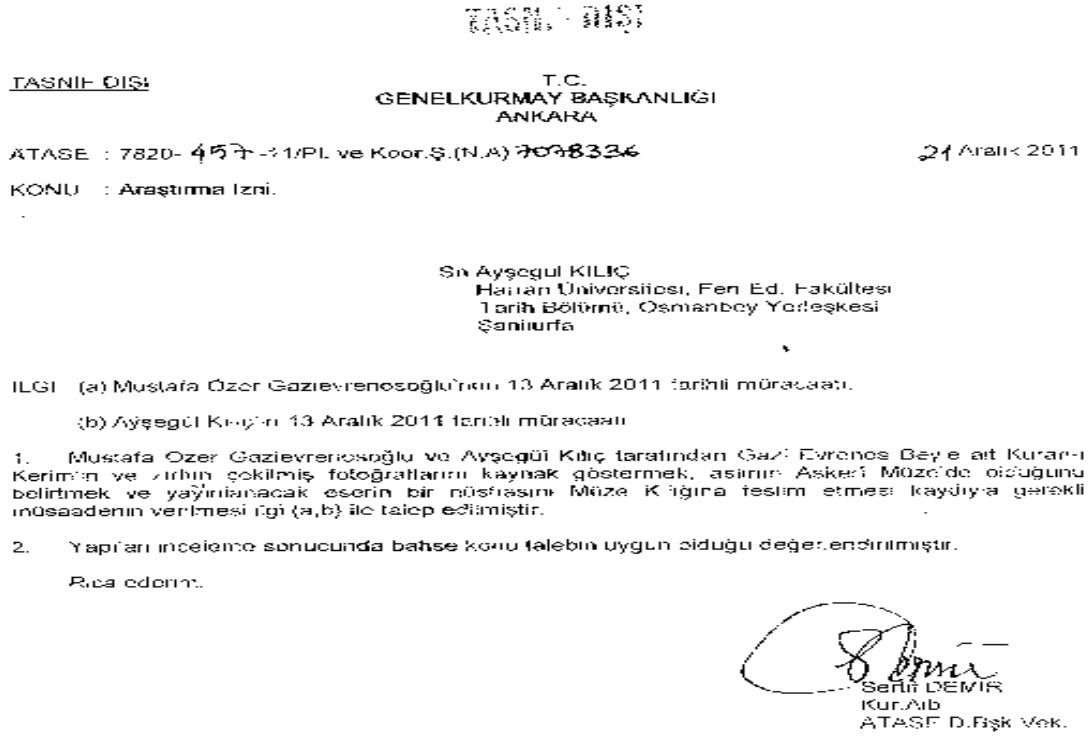

4- H. Lowry, kitabında 'Kılıç'ın iki çalışmasında da üzerinde yazdığı konuyla ilgili bildiklerimizi geliştiren bir bilgi olduğunu söylemek zordur' ifadesiyle çalışmalarımı küçümserken, itirazımı dile getirdiğim Önsöz'den sonra yazdığı eleştirilerinde en azından hakkımı teslim ederek 'aşağı yukarı aynı zamanda benzer sonuçlara ulaşmamızın bilimsel bir faaliyetin doğal bir özelliği' diye yazmak zorunda kaldığını görüyoruz. Ancak burada Doktora tezim ve Belleten'deki yayınımın onun 
'benzer sonuçlara' varmadan aylar önce olduğunu unutturmaya çalışmaktadır. Burada bir soru daha yöneltmek gerekiyor: Mademki benzer sonuçlara vardık, kitabında 'Yeni Bulgu \# 1: Evrenosoğlu hanedanının Etnik Kökenleri adlı bölümde tek bir dipnotta dahi benim bu benzer sonuçlarımdan neden bahsetmedi? Ne ismimden ne yayınlarımdan ne de ulaştı̆̆ım sonuçlardan hiçbir şekilde bahsetmezken kitabının sonunda hakaret dolu bir bölüm ayırırken amacı ne olabilir? Hangi dürüst bir bilim adamı 'benzer sonuçlara' vardığı ve kendisinden önce yazılmış yayınlardan hiç bahsetmeden ve utanmadan 'yeni bulgu' diye ortaya çıkar ki? Kaldı ki okuyucu 'benzer sonuçlar' olarak bahsedilen kısımların neredeyse aynı olduğunu yukarıdaki tablolarda ve alıntılardan izleyebilecektir.

5- H. W. Lowry, okuyucunun gözünde itibarımı zedelemek ve küçük düşürmek için konuyla ilgisi olmayan başka bir makalemi de kitabında bana ayırdığı eleştiri bölümünde yerden yere vuruyor. Bizans ve Osmanlı Kaynaklarında Gazi Evrenos Bey'in İmajı Hakkında Bir Inceleme adlı makalemde Bizans ve Osmanlı kaynaklarından Evrenos'un adının imlası, hakkında neler yazıldığı, olumlu veya olumsuz algıların yanı sıra özellikle adının imlası hakkında da varyasyonları bir araya getirmiştim. H. Lowry bu kaynak gruplarını bir arada kullanmanın elmayla armudu karşılaştırmak kadar ilgisiz olduğunu ileri sürerek aşağılamalarına devam etmiş. Kendisine ait daha önce kaleme alınmış hiçbir eserinde Bizans kaynaklarında Evrenos Bey'in hangi isimle geçtiğine dair bir atıf olmamasına rağmen, Evrenos Bey'in Bizans kaynaklarındaki ilk imajından bahseden S. Reinert Reinert 1991: 765) ve İ.H. Uzunçarş111'nın Uzunçarş1lı 1977: 414-418) makalelerinden de hareketle böyle bir çalışma yapmanın yararlı olacağını düşünmüştüm. Fakat her nasılsa bu eleştirileri yaptığı aynı kitapta, yine eleştirdiği makalemdeki bilgileri bir tablo şeklinde sunduğunu görüyoruz (Lowry 2012: 92-93: Krş. K1lıç 2012: 131-144)). Bu tabloda her nedense hem Bizans hem Osmanlı kaynaklarında Evrenos'un adının farklı imlalarını tabloyla verince orijinal bir çalışma yapmış oluyor! Öyle ya H. Lowry iyi armutları kendi sepetine bütün çürük elmaları benim sepetime atmakta çok mahir görünüyor. Daha önce aklına gelmeyen bir şey yine tesadüfen aklına gelmiş ve en doğrusunu sunmuş! Esasında bu konuda cevap vermeye dahi değmeyecek sı̆̆ eleştirilerine ve konumuzla doğrudan ilgili olmamasına rağmen okuyucunun dikkatini çekmeden geçemeyeceğim için bahsetme gereği duydum. İlgilenenler olursa diye bu makalemi de yine H. Lowry'nin yazdığı bölümle karşılaştırmalarını tavsiye ediyorum.

\section{Son Bir Açıklama:}

Heath W.Lowry'nin kitabının yayınlanmasından maalesef 2013 Mart ayında haberim olabildi. Okuyucuların aklına neden bu kadar geç öğrendiğim sorusu gelebilir. Bu tarihe kadar kitabın yaygın satış ağlarında ve 
internette satıldığına dair herhangi bir bilgi bulamadım. Şanlıurfa'da bulunmam ve şahsi zorluklarımdan dolayı ancak internetteki kitap satış sitelerinden takip edebildiğim için bu sitelerde hiç rastlamadım. Kendisi kitabın Haziran 2012'de çıktığını ve elden dağıttı̆̆ isimleri şahit göstererek piyasada olduğunu iddia ediyor. Şahitliklerine bir şey demeyeceğim ve doğru kabul ediyorum. Kitabın künye sayfasını neden dikkate almadığıma gelince; yayın dünyasına yakın olanların iyi bildiği gibi bir kitabın sadece başlığ1 ve sözleşme ile bakanlıktan telif/copyright-ISBN numarası ve bandrol almak mümkündür. Kitabı daha sonra baskıya gönderebilirsiniz. $\mathrm{Bu}$ nedenle kitap üzerinde yazan 2012 tarihini elbette gördüm. Ancak piyasada rastlamadığım bir kitabın geçen yıl basıldığını gördüğümde Heath W. Lowry'nin bu yola başvurduğunu düşünerek 2014 yılında basılan kitabımın Önsöz'ünde onu baskı tarihini kasıtlı olarak eski göstermekle suçladım. Heath W. Lowry'nin bana cevap olarak yazdığ 1 son yazısında da en çok bu konuda saldırdığını söylemeliyim. Bunun üzerine yayıncı arkadaşların yardımıyla Türkiye'deki en büyük kitap satış ağlarında bu kitabın ne zaman satışa çıktığını öğrenmek istedim. Kendi yanılgımı kabul etmekte sakınca gören biri değilim ama nasıl gözümden kaçtığını merak ettim doğrusu. Araştırmalarım sonucunda şunları öğrendim: Kitap en büyük kitap satış sitelerinden www.kitapyurdu.com, www.idefix.com, www.pandora.com, www. ilknokta.com, www.dr.com, ve benzer pek çok sitede en erken Ocak 2013 tarihinde satılmaya başlamış. Yani kitap çok kısıtlı bir çevrede dolaştıktan aylar sonra satılmaya başlamış. Nedenini bilmiyorum ama Türkiye'nin en büyük kitap dağıtım şirketlerine de 2013'te ulaşmış. Dolayısıyla H. W. Lowry'nin kitabında benim bulgularım ve yorumların sahiplenildiğini, bu da yetmezmiş gibi ağır hakaretlerle eleştirildiğimi gördüğ̈̈mde ancak bu yolla meşrulaştırabileceğini düşündüm. Yani bunu aleni bir şekilde yapabileceğine inanamadım. 2012'de yayınlanmak üzere İthaki Yayınları'na teslim ettiğim kitabım 2014 başında yayınlanmadan önce, birkaç paragrafla düşüncelerimi bu şekilde ifade ettim. Belki iddialarım okuyucuya fazla komplo teorisi gibi görünebilir. Ancak bu şüphede haksız olmadığımın anlattığı hikâyenin tutarsızlıklarından anlaşılacağını umuyorum. Elbette şahsımı ve yayınlarımı görmezden geldiği için bana çıkan kitabını göndermesini veya beni haberdar etmesini beklemiyordum. Ancak bütün bu bilgilere rağmen, hatanın benim olduğunu kabul ederek suçlamalarımdan dolayı özür diliyorum.

Sonuç olarak herhangi birinin benim yaptığım hatalar konusunda eleştirme ve hatta alay etme hakkını kendinde görmesine bir itirazım yoktur. İsteyen istediği gibi düşünebilir veya konuşabilir. Akademik hayatım ilerledikçe daha az hata yapmaya çalışmaktan başka gayretim olmayacaktır. Ancak bu durum yayınlarımın çalınmasına ses çıkarmayacağım, meşru sayacağım ve kişilik katli teşebbüslerine susacağım anlamına gelmez. H. W. 
Lowry'den hatasını kabul ederek intihal yaptığından dolayı özür dilemesini beklemiyorum. Bunu yapmayacağını yazılarındaki üslubundan anlıyorum. Ancak bunu ömür boyu bekleyeceğimi belirtmeliyim. Temennim odur ki Allah ona uzun ömür versin ve kalan zamanında nefsini yenmekle meşgul etsin ${ }^{7}$.

\section{KAYNAKÇA}

167 Numaralı Muhâsebe-i Vilâyet-i Rûm-ili Defteri, (937/1530) I, Dizin ve Tıpkıbasım, Başbakanlık Devlet Arşivleri Genel Müdürlüğü Osmanlı Arşivi Daire Başkanlığı Yay., No: 65, Ankara 2003.

Birinci, Ali (2014), Tarihin Kara Kitabl, Tarihçiliğimizde Usul ve Ahlak Meseleleri, Kitabevi Yay., İstanbul.

BOA, Şura-yı Devlet Evrakı, No: 11/22.

Çalı, Ayşegül (2011), Gazi Evrenos Bey, Ankara Üniversitesi, Sosyal Bilimler Enstitüsü, Ankara.

Demetriades, Vassilis (1976), “The Tomb of Ghazi Evrenos Bey at Yenitsa and its Inscruption”, Bulletin of the School of Oriental and African Studies, v. XXXIX/I, London, 328-332.

Fisk, Robert (2011), Büyük Medeniyet Savaşı, Ortadoğu'nun Fethi, İthaki Yayınları, İstanbul.

Kı1ıç, Ayşegül (2011a), "Evrenos Bey’in Kökeni Hakkında Tartışmalar ve Yeni Bir Değerlendirme, Belleten, (Aralık 2011), c. LXXV, Sayı. 274, s. 745-768.

K1lıç, Ayşegül (2011b), "Bizans ve Osmanlı Kaynaklarında Gâzi Evrenos Bey'in İmaj1 Hakkında Bir İnceleme”, Ankara Üniversitesi Tarih Araştırmaları Dergisi, c. XXX, S. 49, Ankara, s. 131-144.

K1lıç, Ayşegül (2012), “Evrenos Bey'in Babası Pranko Lazarat'ın (Pranko İsa) Vakfı ve Türbesi”, Güneydoğu Avrupa Çalışmaları Uygulama ve Araştırma Merkezi Dergisi, GAMER, c.I, S. 1, Ankara, s. 87-99.

$\mathrm{Bu}$ yazıyı H.W.Lowry'nin yazısına cevaben aynı dergide yayınlamak istedim. Ancak H.W. Lowry'nin de Yayın Kurulu'nda olduğu dergi yönetimi, talebim karşısında uzun süren kararsızlık ve tereddüt yaşadıktan sonra tarafıma şu cevabı yolladı: "Sayın Hocam, cevap talebiniz Yayın Kurulu'muzda görüşülüp karara bağlandı. Yazınızda karşı çıktığınız yazarın şahsına yönelik yorum yapılmamasını ve akademik dünyanın bilgi birikimine katkıda bulunma amacının ötesinde polemiğe yer verilmemesini sizden saygılarımızla rica ediyoruz. Göndereceğiniz yazıyı karşı tarafa gösterme ve buna bir karşı cevap yazılırsa ikisini de aynı sayıda yayınlama hakkımızı saklı tuttuğumuzu bilgilerinize sunarız. ... iyi çalışmalar dileriz. Yayın sekreteri Ertuğrul Ökten.” Okuyucuların takdirine bırakıyorum. 
Kılıç, Ayşegül (2014), Bir Osmanlı Akıncı Beyi: Gazi Evrenos Bey, İthaki Yayınları, İstanbul 2014.

Lowry, Heath W.- Erünsal, İsmail E., (2010), Yenice-i Vardar'lı Evrenos Hanedani: Notlar ve Belgeler, Bahçeşehir Ünv. Yay., İstanbul.

Lowry, Heath W. (2014) "Oyunu Kuralına Göre Oynamak: Ayşegül Kılıç’a Bir Yanıt", Osmanlı Arasstırmaları/The Journal of Ottoman Studies, XLIII, s. 475-492.

Lowry, Heath W. (2012a) Fourteenth Century Ottoman Realities On Dördüncü Yüzyll Osmanlı Gerçekleri, In Search of Hâct- Gâzî Evrenos- Ondördüncü Yüzyıl Osmanlı Gerçekleri, Hacı-Gazi Evrenos'un İzinde, Bahçeşehir Üniversitesi Yayınları, İstanbul.

Lowry, Heath. W. (2012b), "Gazi Evrenos Bey”, Sultan I. Murad Hüdâvendigâr ve Dönemi, ed. İ. Selimoğlu, Gaye Kitabevi, Bursa: 36-76.

Lowry, Heath W. (2003) The Nature of the Early Ottoman State, State University of New York Press, Albany;

Lowry, Heath W. (2010), Erken Osmanlı Devleti'nin Yapısı, İstanbul Bilgi Üniversitesi Yay. İstanbul.

Reinert, Steven W. (1991), "Evrenos”, The Oxford Dictionary of Byzantium, ed. Alexander P. Kazhdan, c.II, Oxford, 765.

Uzunaçarş111, İsmail H. (1977), “Evrenos”, İA, c. IV, İstanbul, s. 414-418. 